\title{
Serodiagnostic Investigation of Syphilis in Taluka Gambat
}

\author{
Sagheer Hussain Shah, Agha Asad Noor* \\ Institute of Microbiology, University of Sindh, Jamshoro, Pakistan
}

\section{ABSTRACT}

Background: Syphilis is a chronic and sexually transmitted infection, caused by Treponema pallidum. Taluka Gambat is an under developing rural area of District Khairpur, Sindh having higher poverty rate. This study was undertaken to assess the morbidity rate of syphilis and awareness about this disease in the population of Gambat.

Objectives: To investigate the prevalence of syphilis in various age groups of male and female population of Taluka Gambat to review the frequency of occurrence of syphilis.

Methodology: This work was done using conventional serological method by collecting data and laboratory diagnosis. Total 437 serum samples from different private and public health units, dispensaries and hospitals in Taluka Gambat were collected between October 2016 to March 2017 and subjected to qualitative testing by VDRL-Immune Chromatography test.

Results: Out of 437 samples, 80 samples (18\%) were reactive in adults of 30-45 years of age and one sample showed positive case in 9 months old boy indicating congenital syphilis $(0.2 \%)$ whereas 373 stood non-reactive. Our results showed a $14 \%$ prevalence of syphilis in Taluka Gambat in the age group between $30-45$ years of age and $0.2 \%$ congenital syphilis. It is an alarming situation due to lack of diagnostic, treatment facilities and awareness about sexually transmitted diseases (STDs).

Conclusion: It is concluded that syphilis is found more or less in all age groups. The highest incidence is observed in population of age group between 30-40 years in Taluka Gambat. Majority infections were found in immunocompromised patients owing to drug abuse and having multiple sex partners.

$\begin{array}{lll}\text { Keywords } & \text { *Address of Correspondence } & \text { Article info. } \\ \text { Syphilis, Gender effect, Age factor, } & \text { aanpathan@usindh.edu.pk } & \text { Received: March 3, 2019 } \\ \text { Serology, Sexually Transmitted Disease. } & & \text { Accepted: January 15, 2020 }\end{array}$

Cite this article: Shah SH, Noor AA. Serodiagnostic Investigation of Syphilis in Taluka Gambat. Funding Source: The cost of this RADS J Biol Res Appl Sci. 2019; 10(2):76-81.

This is an Open Access article distributed under the terms of the Creative Commons Attribution License (http://creativecommons.org/licenses/by/4.0), which permits unrestricted use, distribution, and reproduction in any medium, provided the original work is properly cited. study was borne by the investigator with the partial funding of the supervisor.

Conflict of Interest: Nil

\section{INTRODUCTION}

Syphilis is an ancient sexually transmitted ${ }^{1}$, disease with huge prevalence all around the globe ${ }^{2}$. It is a disease of diversified clinical manifestations ${ }^{1-3}$, caused by Treponema pallidum. According to World Health Organization (WHO) statistics, six million cases are reported every year. About $90 \%$ of them are found in developing countries ${ }^{4}$. The disease is known to be disseminated through oral, vaginal and anal sex contacts, and a significant proportion is of congenital syphilis transmitted from infected mother to the neonate during childbirth. More than 1 million infections of sexual contact have been observed globally per day ${ }^{5}$, reported in 1982.
In untreated Syphilis, T. pallidum invades every organ or system of the body causing damage to all body organs ${ }^{6}$. Less than one million pregnant women showed syphilis after-effects with adverse births and still-birth ${ }^{7}$. The findings showed that the sexually transmitted infections cause severe complications from vertical transmission that eventually leads to death ${ }^{5}$. Homosexual males could be one of the sources of syphilis ${ }^{7}$, whereas in old aged, more than one sexual partners and HIV positive history is also considered risk potential source for syphilis transmission ${ }^{8}$. Other risk factors include prostitution, bisexuality, intravenous drug usage and skin scarification ${ }^{9}$. Primary syphilis disseminates via direct 
contact with infected person through the skin or the mucous membrane ${ }^{10}$.

T. Pallidum is difficult to grow in laboratory ${ }^{4}$ but the serological investigation is a robust, time-tested and widely used method. It is an effective tool for the diagnosis and treatment ${ }^{11-12}$. The agglutination tests with latex particles coated with Treponemal antigen or immune chromatographic strips offer more accuracy in detecting syphilis antibodies. Moreover, this is a cheaper, and quick method $^{13-14}$.

Taluka Gambat belongs to the rural areas of district Khairpur with lower literacy rate. Majority of the population lacks awareness about prevention, diagnosis and treatment of sexually transmitted infections. Homo and heterosexual contact with multiple partners without observing any precaution is a cardinal factor in the spread of syphilis among the population.

The aim of the study is to monitor the frequency of occurrence of syphilis among the male and female population of Taluka Gambat and to highlight the risk factors to the patients and common people for prevention and cure in future.

\section{MATERIALS AND METHODS}

\section{Study Population}

Survey of 437 syphilis patients from Taluka hospital was undertaken. This study was based on the detection of syphilis disease in the patients of various age groups of both genders by serodiagnostic method during 2016-17.

\section{Ethical Approval}

The topic of research was approved by Board of Advanced Studies and Research, University of Sindh, Jamshoro.

\section{Inclusion Criteria}

During research work, the blood samples were collected from the patients showing clinical signs possibly indicating syphilis from various hospitals of Taluka Gambat.

\section{Collection of Serum Samples}

Blood samples were collected from the patients from different hospitals and brought to the laboratories under standard methods of transportation by using vacutainer tube. $3 \mathrm{cc}(\mathrm{BD})$ of blood was withdrawn by vein puncture, samples were properly labelled and stored for further processing.

\section{VDRL-ICT Test}

The serum samples $(50 \mu l)$ were transferred by micropipette to the respective wells of VDRL-ICT kit (ImuMed, USA), followed by addition of 2 drops of buffer and left for 15 minutes at room temperature. After incubation, results were recorded as per instructions of the manufacturer.

\section{RESULTS AND DISCUSSION}

This study was carried out to find the prevalence of syphilis among the population of Taluka Gambat. The samples from various hospitals were obtained and analyzed for the prevalence of syphilis. A total of 437 blood samples from male and female patients were investigated from various areas of Taluka Gambat. Sampling was done during the period of October 2016 till March, 2017. The specimens were tabulized according to the age and gender of the patient for the prevalence of syphilis (Table 1). The samples were also classified according to the time of collection (Table 2).

As being a sexually transmitted disease, it is more likely that there may be higher burden of other STDs as well, including HIV, Hepatitis A and B. As the detection of syphilis is easier and economical than other STDs it may be used as indicator for the prediction of other diseases sharing the similar mode of transmission with it. ${ }^{15-19}$ Although syphilis can be prevented by using condoms and cured easily by using commonly available antimicrobial therapy. The major problems concerning the spread of syphilis in rural societies are lack of awareness, social stigma associated with STDs, rural traditions and misconceptions about venereal diseases. Poverty and unemployment among rural population results in their involvement in drugs, in particular, intravenous drug abuse could be a vehicle for transmission. As the disease could be asymptomatic among female patients, they play an important role in the spread of the disease not only to their partners but also to their children.

Our results of serodiagnosis from October to December 2016 and January to March 2017 revealed 15, 16, 15 and $11,13,13$ positive cases from $65,78,70$ and $63,81,80$ collected samples from various age groups of male and 
female patients, respectively (Table 2-3). Pakistan, comprising of male dominancy has huge numbers of the patients having sexually transmitted disease, ignorance of using condoms and therapeutic measures of sexual diseases ${ }^{20}$. Our country is also affected from these worst diseases that not only affect the partner but also the children. It is known as a major complication of disability and preventable deaths among the newly born babies and infants ${ }^{21-23}$. Previously, a study has been conducted by National AIDS Control Program among high-risk people in Lahore and Karachi including injection drug users. In rural areas, this disease mainly spread by sex workers having sex with multiple partners including drug addicts syphilitic partners. Contaminated hospital instruments are also a mean to spread the disease, health workers and individuals belonging to a poor socioeconomic background such as industrial workers, unemployed persons having stress, vehicle drivers and illiterate persons have a higher incidence of the infection ${ }^{24-25}$.

Table 1. Comparative Analysis of Samples with Respect to Age Group.

\begin{tabular}{ccc}
\hline Age (Years) & Total No. of Samples Collected & Total No. of Positive (Reactive) Samples \\
\hline $1-10$ & 06 & 1 \\
\hline $11-20$ & 48 & 0 \\
\hline $21-30$ & 106 & 5 \\
\hline $31-40$ & 144 & 60 \\
\hline $41-50$ & 133 & 14 \\
\hline Total & $\mathbf{4 3 7}$ & $\mathbf{8 0}$ \\
\hline
\end{tabular}

Table 2. Total Number of Samples Collected and Positive (Reactive) Samples from Various Age Group from October - December 2016.

\begin{tabular}{|c|c|c|c|c|c|c|}
\hline \multirow{3}{*}{$\begin{array}{c}\text { Age } \\
\text { (Years) }\end{array}$} & \multicolumn{6}{|c|}{ Samples Analysis - 2016} \\
\hline & \multicolumn{2}{|c|}{ October } & \multicolumn{2}{|c|}{ November } & \multicolumn{2}{|c|}{ December } \\
\hline & $\begin{array}{c}\text { No. of } \\
\text { Samples } \\
\text { Collected }\end{array}$ & $\begin{array}{l}\text { No. of Positive } \\
\text { (Reactive) } \\
\text { Samples }\end{array}$ & $\begin{array}{c}\text { No. of } \\
\text { Samples } \\
\text { Collected }\end{array}$ & $\begin{array}{c}\text { No. of Positive } \\
\text { (Reactive) } \\
\text { Samples }\end{array}$ & $\begin{array}{c}\text { No. of } \\
\text { Samples } \\
\text { Collected }\end{array}$ & $\begin{array}{c}\text { No. of Positive } \\
\text { (Reactive) } \\
\text { Samples }\end{array}$ \\
\hline $1-10$ & 00 & 00 & 02 & 00 & 01 & 00 \\
\hline $11-20$ & 02 & 00 & 09 & 00 & 10 & 00 \\
\hline $21-30$ & 20 & 01 & 13 & 01 & 17 & 01 \\
\hline $31-40$ & 22 & 11 & 30 & 13 & 30 & 12 \\
\hline $41-50$ & 21 & 03 & 24 & 02 & 12 & 02 \\
\hline Total & 65 & 15 & 78 & 16 & 70 & 15 \\
\hline
\end{tabular}

Table 3. Total Number of Samples Collected and Positive (Reactive) Samples from Various Age Group from January - March 2017.

\begin{tabular}{ccccccc}
\hline & \multicolumn{6}{c}{ Samples Analysis - 2017 } \\
\cline { 2 - 7 } Age \\
\cline { 2 - 7 } (Years) & \multicolumn{2}{c}{ January } & \multicolumn{2}{c}{ February } & \multicolumn{2}{c}{ March } \\
& $\begin{array}{c}\text { No. of } \\
\text { Samples } \\
\text { Collected }\end{array}$ & $\begin{array}{c}\text { No. of Positive } \\
\text { (Reactive) } \\
\text { Samples }\end{array}$ & $\begin{array}{c}\text { No. of } \\
\text { Samples } \\
\text { Collected }\end{array}$ & $\begin{array}{c}\text { No. of Positive } \\
\text { (Reactive) } \\
\text { Samples }\end{array}$ & $\begin{array}{c}\text { No. of } \\
\text { Samples } \\
\text { Collected }\end{array}$ & $\begin{array}{c}\text { No. of Positive } \\
\text { (Reactive) } \\
\text { Samples }\end{array}$ \\
\hline $1-10$ & 02 & 00 & 00 & 00 & 01 & 01 \\
\hline $11-20$ & 04 & 00 & 14 & 00 & 06 & 00 \\
\hline $21-30$ & 20 & 01 & 20 & 02 & 18 & 00 \\
\hline $31-40$ & 16 & 07 & 21 & 11 & 24 & 08 \\
\hline $41-50$ & 21 & 03 & 26 & 00 & 31 & 04 \\
\hline Total & 63 & $\mathbf{1 1}$ & $\mathbf{8 1}$ & $\mathbf{1 3}$ & $\mathbf{8 0}$ & $\mathbf{1 3}$ \\
\hline
\end{tabular}


Table 4. Determination of Percentage of Positive (Reactive) Cases of Syphilis in Various Age Groups from October 2016 To March 2017.

\begin{tabular}{|c|c|c|c|c|c|c|}
\hline \multirow{3}{*}{ Age Groups } & \multicolumn{6}{|c|}{ Percentage (\%) of Positive (Reactive) Cases } \\
\hline & \multicolumn{3}{|c|}{2016} & \multicolumn{3}{|c|}{2017} \\
\hline & Oct & Nov & Dec & Jan & Feb & Mar \\
\hline $1-10$ & 00 & 00 & 00 & 00 & 00 & 0.2 \\
\hline $11-20$ & 00 & 00 & 00 & 00 & 00 & 00 \\
\hline $21-30$ & 0.2 & 0.2 & 0.2 & 0.2 & 0.45 & 00 \\
\hline $31-40$ & 2.5 & 3.0 & 2.7 & 3.7 & 2.5 & 1.8 \\
\hline $41-50$ & 0.7 & 0.45 & 0.45 & 0.7 & 00 & 0.9 \\
\hline
\end{tabular}

The month-wise determination of the percentage of syphilis in all age groups showed $00,00,0.2,2.5,0.7 \%$; $00,00,0.2,3,0.45 \% ; 00,00,0.2,2.7,0.45 \%$ during October to December, 2016 whereas 00, 00, 0.2, 3.7, $0.7 \% ; 00,00,0.45,2.5,00 \% ; 0.2,00,00,1.8,0.9 \%$ in $1-$ $10,11-20,21-30$ and $41-50$ years of patients during January to March, 2017 (Table 3). A six months study in 2016 and 2017 revealed no reactive results in 2016 whereas $0.2 \%$ was observed in March 2017 in 1-10 years of patients. During the month of Feb, 2017 a bit greater incidence $(0.45 \%)$ was reported in 21-30 years of patients and in the January 31-40 years patients were observed to have greater percentage of syphilis $(3.7 \%)$ in January, 2017 whereas the patients of 41-50 years had been suffering since long time and showed the greater percentage of occurrence in Oct, $2016(0.7 \%)$ and $(0.9 \%)$ in March, 2017 (Table 4).

These findings indicate that the increasing ratio and the prevalence of syphilis are due to lack of early and proper diagnosis in the rural areas. The culturing of Treponema pallidum is quite difficult and could be substituted with serodiagnostic methods for rapid diagnosis to detect syphilis of secondary, latent, and tertiary stages ${ }^{5-17,26-28}$. Mainly two tests i.e. rapid plasma regain (RPR) test and venereal disease research laboratory (VDRL) are significant in the easy diagnosis worldwide ${ }^{15-17,27-29}$.

Serological tests are easier and approachable with high sensitivity and specificity to screen out the individuals with non-symptomatic syphilis and can also confirm prevalence in the symptomatic individuals ${ }^{15-16,26-27}$. This study is based on inexpensive, rapidly performed, nontreponemal tests such as venereal disease research laboratories test that shows the antibody titer against a lipoidal antigen ${ }^{30}$. Our results of six months cross sectional study revealed $19 \%$ prevalence of syphilis in genera whereas the greater incidence of syphilis is observed among the adults between 31-40 years of age having $43 \%$ of prevalence as compared to the patients of other age groups.

\section{CONCLUSION}

Based on our results, it is concluded that syphilis is found more or less in all age groups. The highest incidence is observed in population of age group between $30-40$ years in Taluka Gambat. Majority infections were found in immunocompromised patients owing to drug abuse and having multiple sex partners. It is concluded that 1-10 years of kids have syphilis due to the transmission from mother during birth. Stillbirth and miscarriage rate among infected mothers is undocumented and needs the attention of health authorities. These finding also suggest the infection peak during the winter season. These finding also point indirectly towards the potential presence of other infections having similar mode of transmission.

\section{ACKNOWLEDGEMENT}

I acknowledge sincere thanks to my supervisor for providing funds for the purchase of kits. 


\section{LIST OF ABBREVIATIONS}

WHO

STDS

RPR

VDRL
World Health Organization

Sexually Transmitted Diseases

Rapid Plasma Reagin

Venereal Disease Research Laboratory

\section{REFERENCES}

1. Felman YM, Nikitas JA. Sexually transmitted diseases. Primary Syphilis. Cutis. 1982; 29(2):122-4.

2. WHO. World Health Organization. Global prevalence and incidence of selected curable sexually transmitted infections: overview and estimates. (2001).

3. Korenromp EL, Rowley J, Alonso M, Mello MB, Wijesooriya NS, Mahiané SG, et al. Global burden of maternal and congenital syphilis and associated adverse birth outcomes-Estimates for 2016 and progress since 2012. PLoS ONE. 2019; 14(2):e0211720.

4. Fieldsteel $\mathrm{AH}, \mathrm{Cox} \mathrm{DL}$, Moeckli RA. Cultivation of virulent Treponema pallidum in tissue culture. Infect Immun. 1981; 32(2):908-15.

5. Norris SJ. In vitro cultivation of Treponema pallidum: Independent confirmation. Infect Immun. 1982; 36:437-39.

6. WHO. World Health Organization. What are sexually transmitted infections and how are they transmitted? 2017.

7. Hu X, Qu B, Liu J, Wu YX, Wang DB. Analysis of the epidemiological features and prediction of the trend of syphilis in China between 1990 and 2011. Mod Prev Medi. 2014; 6:961-71.

8. Newman L, Kamb M, Hawkes S, Gomez G, Say L, Seuc A, et al. Global estimates of syphilis in pregnancy and associated adverse outcomes: analysis of multinational antenatal. Surveillance data. PLOS Med. 2013; 10(2):1-10.

9. Vall-Mayans $M$, Casals $M$, Vives A, Loureiro $E$, Armengol P, Sanz B. Reemergence of infectious syphilis among homosexual men and HIV co-infection in Barcelona, 2002-2003. Med Clin (Barc). 2006; 126:94-6.

10. Vera L, Milka D, Nurith SL, Eilat S. Prevalence and incidence of syphilis among volunteer blood donors in Israel. J Blood Transfus. 2014; 1-7.doi: 10.1155/2014/154048

11. Eccleston K, Collins L, Higgins SP. Primary syphilis. Int J STD AIDS. 2008; 19:145-51.

12. Park IU, Chow JM, Bolan G, Stanley M, Shieh J, Schapiro JM. Screening for syphilis with the Treponemal immunoassays: Analysis of discordant serology results and implications for clinical management. J Infect Dis. 2011; 204:1297-304.

13. Tong M, Lin L, Liu L, Zhang H, Huang S, Chen YY, et al. Analysis of 3 algorithms for syphilis serodiagnosis and implications for clinical management. Clin Infect Dis. 2014; 58(8):1116-24.

14. Sena C, White BL, Sparling PF. Novel treponema pallidum serologic tests: a paradigm shift in syphilis screening for the 21st century. Clin Infect Dis. 2010; 51:700-8.

15. Van Dommelen L, Smismans A, Goossens VJ, Damoiseaux J, Bruggeman CA, van Tiel FH, et al. Evaluation of a rapid one-step immunochromatographic test and two immunoenzymatic assays for the detection of antiTreponema pallidum antibodies. Sex Transm Infect. 2008; 84:292-96.

16. Kinghorn GR. Syphilis and bacterial sexually transmitted infections. In: Burn T, Breathnach S, Cox N, Griffiths C. editors. Rook's Textbook of Dermatology. Oxford: Wiley-Blackwell; 2010. p.34-37.

17. Sanchez MR. Syphilis. In: Fitzpatrick's dermatology in general medicine. Wolff $\mathrm{K}$, Goldsmith LA, Katz SI, Gilchrest BA, Paller AS, Leffell DJ. editors. New York: McGraw Hill; 2008. p.1955-77.

18. French P. Syphilis. BMJ. 2007; 334:143-74.

19. Golden MB, Maeea MB, Holmes KK. Update on syphilis, a resurgence of an old problem. JAMA 2003; 290:1510-14.

20. Goh BT. Syphilis in adults. Sex Transm Infect. 2005; 81:448-52.

21. Rehan N. Profile of men suffering from sexually transmitted infections in Pakistan. J Pak Med Assoc. 2006; 56:60-5.

22. WHO. World Health Organization. Global HIVIAIDS response: epidemic update and health sector progress towards universal access. 2011.

23. WHO. World Health Organization. The global elimination of congenital syphilis: rationale and strategy for action. 2007.

24. WHO. World Health Organization. The investment case for eliminating mother-to-child transmission of syphilis: promoting better maternal and child health and stronger health systems. 2012.

25. Shah SA, Kristensen S, Memon MA, Usman G, Ghazi $A$, John $R$, et al. Prevalence of syphilis among antenatal clinic attendees in Karachi: Imperative to begin universal screening in Pakistan. J Pak Med Assoc. 2011; 61(10):993-7.

26. Defraye A, Sasse A. STI surveillance by a sentinel network of physicians in Belgium. Acta Clin Belg. 2005; 60(2):70-4. 
27. Singh E, Romanowski B. Syphilis: Review with emphasis on clinical, epidemiologic, and some biologic features. Clin Micro biol Rev. 1999; 12(2):187-209.

28. Egglestone SI, Turner AJ. Serological diagnosis of syphilis. PHLS Syphilis Serology Working Group. Commun Dis Pub Health. 2000; 3:158-62.
29. Young $H$. Guidelines for serological testing for syphilis. Sex Transm Infec. 2000; 76:403-5.

30. Kamalin A, Nunn AJ, Mulder DW, Van Dyck E, Dobbins JG, Whitworth JA. Seropositivity and incidence of genital ulcer infections in a rural Ugandan population. Sex Transm Infect. 1999; 75(2):98-102. 